\title{
A Study of the Effect of Education and Academic Environment on Emotional Intelligence on Accounting Students in Iran
}

\author{
Mahdi Salehi ${ }^{1}$, Mohammadreza Abbas Zadeh ${ }^{1}$, Alireza Ghaderi ${ }^{2}$ \& Alaleh ZhianTabasi ${ }^{1}$ \\ ${ }^{1}$ Department of Accounting, Ferdowsi Uniuversity of Mashhad, Mashhad, Iran \\ ${ }^{2}$ Department of Psychology, Ferdowsi Uniuversity of Mashhad, Mashhad, Iran \\ Correspondence: Mahdi Salehi, Department of Accounting, Ferdowsi University of Mashhad, Mashhad, \\ Khorasan Razavi province, Iran. E-mail: mehdi.salehi@fum.ac.ir
}

Received: June 5, 2015 Accepted: July 23, 2015 Online Published: December 29, 2015

doi:10.5539/ies.v9n1p182 URL: http://dx.doi.org/10.5539/ies.v9n1p182

\begin{abstract}
The current study aims to investigate the relation between education and academic environment on emotional intelligence of accounting students in state and non-state universities in Iran.

In order to collecting data Bar-on emotional intelligence test and SCL 90 questionnaire administrated among 476 students in different subjects including accounting in both Bachelor and Master degrees in 2014. Pearson correlation coefficient, variance analysis test and covariance analysis employed for analyzing data.

The results of the study indicate that there is not a significant difference between changes of emotional intelligence scores in accounting students with non-accounting ones and also there is no meaningful difference between students of state and non-state universities in Iran.

The current study focuses on education and academic environment on emotional intelligence of accounting students which is the first study is conducted in Iran.
\end{abstract}

Keywords: emotional intelligence, accounting education, gender, mental health

\section{Introduction}

Emotional intelligent increases individuals` ability to identify, manage and use emotions. Necessity of applying emotional intelligent is a response to growing researches indicating workplace is not only a logical environment. Although during decision-making individuals face problems based on emotions, but decision-making is much harder infields like accounting which follows rationalism and certain regulations, in spite of presence of emotions (Mcphail, 2004). So, it can conclude that the not only emotion does not make a problem in contemporary capitalist organizations (Ashkanasy, Hartel, \& Daus, 2002). Emotion and mind are not against each other, they do have close relationship with each other (Ashkanasy, Hartel, \& Daus, 2002). Therefore, the aspect that accounting profession is not a function of rationality is not acceptable and emotion as an effective factor in accounting profession should be taken into account. With this description, it is necessary to pay special attention to emotions in academic trainings, especially in accounting major. We also need to care about identifying and recognizing social, economic and moral consequences which are result of applying emotions and their effect on decision-making should also be taken into account (Mcphail, 2004). Universities should meet markets ' expectations and they should make sure that markets gain necessary skill and knowledge. Also, it is necessary to make sure that those graduated are ready for starting profession (Pan \& Hector, 2011). Accounting efficiency in companies depends on their accountant's quality and the quality is directly influenced by qualification levels and their knowledge. Today, professional accountants are facing too much unexpected conditions and the necessity of change or revisions in accounting education is felt and understood very well in order to achieve better performance of accountants in these unexpected conditions. According to discussions above, the problem is raised that if academic trainings in accounting major and other majors at universities can increase students' emotional intelligence level? Does gender and type of university influence on place of education? 


\section{Theoretical issues}

\subsection{Intelligence and Types of Intelligence}

Psychologists believe that intelligence is a set of individuals' abilities by which individuals understand something and think and conduct logically. Researches indicate that there exits multiple intelligences which are independent of each other totally. Gardner (1993) shows different types of intelligence which grow up independently of each other and each skill is for certain area of brain. According to Gardner's research, multiple intelligences are as follows:

Physical quotient: It is the ability of skillful control of body movement and using things.

Intelligence quotient: This type of intelligence is cared in educational system, and it is related to our logical skills.

Emotional quotient: It has a key role regarding achieving success in the market and contributes us in establishing communications and somehow has the ability of prediction.

Also, it indicates what deeds are appropriate and inappropriate in social relation and special conditions. In other words, emotional intelligence is the ability of having a close relationship with others and listening to individuals' feelings.

Spiritual quotient: It includes inner guidance and wisdom, keeping equanimity, inner, outer and functional peace along with insight.

Emotional skill: Emotion includes an intense and short organism reaction to an unexpected position along with pleasant or unpleasant emotional conditions (Khaef \& Ahmadali, 2003). Emotional intelligence can be considered as learning ability and changes of emotions. In fact, individuals with high level of emotional intelligence can explain their emotions and can understand their emotional characteristics and experiences in a two-way relationship between them. Also this makes individuals able to express their motions in a significant way and can organize their emotions in an appropriate manner.

\subsection{Significance of Emotional Intelligent in Accounting}

Soft skills have long been raised as a wide need (including ability of group work, ability of managing problems, leadership and decision-making). In this respect, Kavang and Drennan (2008) claim that accounting professors should move towards training accountants with general skills and should avoid teaching only technical skills. Weber et al., (2009) defined general skills as using personal, behavioral and human skills for applying technical skills and knowledge in workplace. In fact, it can be argued that general skills are associated with emotional intelligence (Bloch, Brewer, \& Stout, 2012). Also by investigating some articles, De Villiers (2010) claims general skills which are taken into account during training are classified into five main categories:

1) Communication skills

2) Skill of solving problem and critical thinking

3) Leadership and workgroup

4) Moral and spiritual values

5) Self-management

As it was argued, confidence in dealing with general skill expansion by accounting training programs is a key issue which is cared by researchers and international federation of accounting, since proficiency in general skills makes professional accountants successfully use the knowledge they learn, the knowledge learned from their public trainings in workplace (International Federation of Accountants, 2014).

According to above suggestions, we can argue that with the rise of students` emotional intelligence during learning, they will be provided with some skills which will make them work as a professional accountant in the current complex and changing environment.

\section{Research Hypotheses Development}

\subsection{Accounting and Emotional Intelligence}

Skills such as communication and workgroup along with technical skills are emphasized in the charts of properties of the most important professional organizations (Cook et al., 2011). Moreover, Association to Advanced Collegiate Schools of Business (AACSB) advice that commerce courses should not be limited to selecting management courses only, rather courses from other majors should be included such as philosophy, math and communication. Argument over necessity of adding general courses along with specialized courses in 
accounting periods has a long background (Cook et al., 2011). The assumption is that more training of general courses can increase skills such as communication, critical thinking and moral reasoning (AACSB, 2010). Also, students` emotional intelligence can increase by passing more general courses during education in B.A. Hence, it is assumed that students' emotional intelligence is different in two majors of accounting and non-accounting. Based on this, following hypothesis is postulated:

$\mathbf{H}_{\mathbf{1}}$ : With controlling mental health variable, there is a significant difference between changes in emotional intelligence scores of accounting students and non-accounting ones.

\subsection{Gender and Emotional Intelligence}

There has been little study on gender and educational success at universities; however their results are different (Fallan \& Opstad, 2014). Some of the researches indicate significance of relationship between gender and educational success in accounting major (Doran, Marvin, \& Smith, 1991). In some researches women`s emotional intelligence level is more than men (Adeyemo, 2008). On the other hand, there have been studies which demonstrate lack of EI difference among women and men (Nasir \& Masrur, 2010; Monem, 2007). Regarding effect of gender on educational success among accounting students Carpenter, Friar and Lyle (1993) indicated women have better performance than men. They suggested although accountant women make more efforts than men, there is no significant difference in their performance. Based on this, following assumptions were explained to study effect of gender on emotional intelligence of woman and man students at universities of Iran:

$\mathbf{H}_{2}$ : With controlling mental health variable, there exists a significant difference between changes in emotional intelligence score among woman and man students.

\subsection{Type of University and Emotional Intelligence (EI)}

According to the research literature which studied in the previous sections of the current study, we can claim that academic environment may be effective on EI. Hence, following hypothesis postulated, and the study conducted among state and non-state universities:

$\mathbf{H}_{3}$ : With controlling mental health variable, there exists a significant difference between changes in emotional intelligence score of state and non-state universities.

\section{Review of Related Literature}

Carr and Mathews (2004) dealt with accounting courses regard it necessary for accountants to learn in the current changing environment in the same way. They suggest including general courses in accounting contributes to learning in the usual way. Diamond (2005) argues that in the current changing environment it is necessary to be interested in learning and presenting new information moreover having specialized information. Clarke (2006) preferred training during work to academic education regarding improvement in EI. He believes performing tasks at work may not lead to rise in EI level; however exchanging ideas, feedbacks and opportunities are effective in increasing EI level. Comparing employed individuals' opinions in their profession and by studying advantages and disadvantages of training, Paisey (2009) concluded that including training in curriculum can be useful for students. He argued although specialized information is regarded as the basis for accountants; accountants widely rely on general skills. Cook et al., (2011), studied role of academic training in accounting and work experience of accounting students in their EI. The results emphasized on improvement of accounting curriculum at universities. They also found out we need to prepare a condition where accounting students can achieve work experience in their field which is associated with their own proficiency. Dhess (2011) noticed identifying practical approaches for using EI in decision-making process. Findings indicate organizations and individuals who are provided with findings related to EI can achieve better results in individual and group decisions. Mostaghimi and Dehbashi (2014) indicate there is a positive and significant correlation between EI and organization commitment. Ehsani, Saba, Jahanian, and Kheirkhah (2014) studied the relation between academic condition and EI among dental students at Medical Sciences University in Iran. They results indicated that there is no significant difference between EI in different inputs, but women's total EI score of is substantially more than men.

\section{Research Methodology}

Statistical society of the research are students in accounting, political sciences, Persian Literature, social sciences and English Language who are studying at state and non-stet Universities of Iran during the end of 2014. Using Morgan Table, we achieved similar answers and at last 476 questionnaires collected from total research society, 25 of which removed from analysis due to lack of profile questions completion. The questionnaire used in the research was standardized Baron and appropriate tests were conducted for measuring validity and reliability. 
Reliability coefficient of Bar-on questionnaire in researches which have been conducted so far was accepted. Samouey (2003) calculated reliability of questionnaire by internal consistency method by Cronbach Alpha of (0.93) and by odd/even days (0.88). Results of studies from Zavareghi and Fatahzade (2006) demonstrated acceptable reliability.

\section{Research Results}

Table 1 presents the descriptive statistic of mental health.

Table 1. Descriptive results of comparing mental health of state and non-state universities students

\begin{tabular}{lllll}
\hline Factor & University & No. & Average & S.d \\
\hline \multirow{2}{*}{ Aggression } & State & 270 & 0.4597 & 0.15418 \\
& Non-state & 181 & 0.4567 & 0.14810 \\
Anxiety & State & 270 & 0.4568 & 0.17778 \\
Obsession & Non-state & 181 & 0.4715 & 0.17749 \\
\multirow{3}{*}{ Interpersonal sensitivity } & State & 270 & 0.3330 & 0.14980 \\
& Non-state & 181 & 0.3238 & 0.14659 \\
Somatization & State & 270 & 0.4660 & 0.22986 \\
& Non-state & 181 & 0.4606 & 0.23288 \\
Psychosis & State & 270 & 0.3859 & 0.18248 \\
Paranoid imagination & Non-state & 181 & 0.3832 & 0.18834 \\
& State & 270 & 0.4250 & 0.17259 \\
& Non-state & 181 & 0.4171 & 0.16988 \\
& State & 270 & 0.3942 & 0.17884 \\
& Non-state & 181 & 0.3849 & 0.16790 \\
Depression & & & & \\
\hline \multirow{3}{*}{ Phobia } & State & 270 & 0.4679 & 0.19970 \\
& Non-state & 181 & 0.4487 & 0.19646 \\
& State & 270 & 0.4322 & 0.18402 \\
& Non-state & 181 & 0.4227 & 0.18192 \\
\hline
\end{tabular}

Above table presents descriptive factors for each one of mental health variable indices for state and non-state universities.

Table 2. Inferential results of comparing mental health state and non-state universities students

\begin{tabular}{lllll}
\hline Factor & D.f & Average differences & T & Sig. \\
\hline Aggression & 449 & 0.00295 & 0.202 & 0.840 \\
Anxiety & 449 & -0.01416 & -0.859 & 0.391 \\
Obsession & 449 & 0.00921 & 0.645 & 0.519 \\
Interpersonal sensitivity & 449 & 0.00542 & 0.244 & 0.807 \\
Somatization & 449 & 0.00263 & 0.148 & 0.882 \\
Psychosis & 449 & 0.00787 & 0.478 & 0.663 \\
Paranoid & 449 & 0.00934 & 0.557 & 0.578 \\
Depression & 449 & 0.01961 & 1.005 & 0.315 \\
Phobia & 449 & 0.09570 & 0.544 & 0.587 \\
\hline
\end{tabular}


As it can be observed that the score of two student groups at state and non-state universities is more than 0.05 , therefore equality assumption for averages of the two groups is approved and no difference is observed between them in each of the indexes.

Table 3. Results of inferential statistics for comparing mental health of men and women students

\begin{tabular}{lllll}
\hline Factor & D.f & Average differences & T & Sig. \\
\hline Aggression & 449 & -0.00529 & -0.354 & 0.724 \\
Anxiety & 449 & -0.02257 & -1.290 & 0.198 \\
obsession & 449 & 0.00246 & 0.168 & 0.866 \\
Interpersonal sensitivity & 449 & -0.01041 & -0.457 & 0.648 \\
Somatization & 449 & -0.04237 & -2.340 & 0.020 \\
Psychosis & 449 & -0.03451 & -2.05 & 0.041 \\
Paranoid imagination & 449 & 0.02244 & 1.307 & 0.192 \\
Depression & 449 & -0.01558 & -0.796 & 0.426 \\
Phobia & 449 & -0.00473 & -0.262 & 0.793 \\
\hline
\end{tabular}

Also the results for the two groups in accounting and non-accounting majors were similar which were refrained in order to prevent from too much repetition.

\section{Hypotheses test:}

\section{The first hypothesis:}

With controlling mental health variable, there exists a significant relationship between changes in EI score among accounting and non-accounting students. According to presence of two variables indiscrete two-level grouping, in order to study the hypothesis, two-factor variance analysis test used.

Table 4. Results of the first hypothesis test

\begin{tabular}{llll}
\hline Changes source & Average squares & F & Sig. \\
\hline Accounting students & 53.18 & 0.947 & 0.201 \\
non-accounting students & 40.71 & 0.863 & 0.173 \\
Two-variable interaction & 12.55 & 0.701 & 0.423 \\
\hline
\end{tabular}

As it can be observed from results in Table No. 4, there is no significant difference from aspect of EI among two student groups of the first and fourth years.

Finally, in two variables of academic year and major in EI variable does not establish a significant difference.

\section{The second hypothesis:}

With controlling mental health variable, there exists a significant difference between changes in EI score of woman and man students.

Table 5. Results of the second hypothesis test

\begin{tabular}{llll}
\hline Changes source & MS & F & Sig. \\
\hline First variable (educational year) & 50.91 & 0.892 & 0.224 \\
Second variable (gender) & 120.33 & 5.249 & 0.00 \\
Interaction of two variables & 11.82 & 1.364 & 0.141 \\
\hline
\end{tabular}

As the results in above table indicate that there is no significant difference among two groups of the first and 
fourth year students from aspect of EI. Further, there is a significant difference among two groups of woman and man students from aspect of EI.

The third hypothesis: With controlling mental health variable, there exists a significant relationship between changes of EI score among state and non-state university students. In order to study the hypothesis, two-factor variance analysis test was applied due to presence of two discrete two-level grouping variables (academic year and university) and one-time measurement.

Table 6. Results of the third hypothesis test

\begin{tabular}{llll}
\hline Changes sources & MS & F & Sig. \\
\hline Firs variable (educational year) & 50.7 & 0.924 & 0.241 \\
Second variable (university) & 61.71 & 1.428 & 0.109 \\
Interaction of two variables & 14.68 & 0.847 & 0.513 \\
\hline
\end{tabular}

As above results indicate, there is no a significant difference among two groups of the first year and fourth year students among two groups of state and non-state university groups. Finally, engagement of the two variables of academic year and gender does not establish a significant difference in EI variable.

\section{Discussion}

The results show that there is no significant differences between changes in EI score of accounting and non-accounting students; On the other hand, specialized and general courses which are passed during educational years lack such as capacity for improving EI of the students. Further, based on the results presented, EI score of women is significantly different with men and EI level of women is more than men. But changes of their EI level are not significantly different and therefore the second hypothesis was not accepted. In fact, according to effects of EI from social, cultural, and economic condition of society the main reason behind this conclusion. Hence, no difference was observed between state and non-state university students across and the third hypothesis was not approved. By the way, variables of measuring mental health had negative correlation with EI and EI level increased with reduction of variable level. Hence, in this research mental health variable was controlled as an effective variable on EI. Based on the test result for comparing mental health variable in the case study groups, the variable has been equal in the all groups.

\section{References}

Adeyemo, D. (2008). Demographic characteristics and emotional intelligence among workers in some selected organizations in Oyo State, Nigeria. Vision-The Journal of Business Perspective, 12(1), 70-85. http://dx.doi.org/10.1177/097226290801200106

American Psychiatric Association. (2000). Diagnostic and statistical manual of mental disorders Text Revision (DSM-IV-TR) (4th ed.). Washington, DC: American Psychiatric Association. http://dx.doi.org/10.1176/appi.books.9780890423349

Ashkanasy, N., Hartel, C., \& Daus, C. (2002). Diversity and emotion: the new frontiers in organizational behavior research. Journal of Management, 28(3), 30-38. http://dx.doi.org/10.1177/014920630202800304

Association to Advance Collegiate Schools of Business (AACSB). (2010). Eligibility procedures and accreditation standards for business accreditation. Retrieved from http://www.aacsb.edu

Bloch, J., Brewer, P. C., \& Stout, D. E. (2012). Responding to the leadership needs of the accounting profession: a module for developing a leadership mindset in accounting students. Issues in Accounting Education, 27(2), 525-554. http://dx.doi.org/10.2308/iace-50125

Carpenter, V., Friar, S., \& Lyle, M. (1993). Evidence on the performance of accounting students: Race, gender and expectations. Issues in Accounting Education, 8, 1-17.

Clarke, N. (2006). Emotional intelligence training: A case of caveat emptor. Human Resource Development Review, 5(4), 422-441. http://dx.doi.org/10.1177/1534484306293844

Cook, G., Bay, D., Visser, B., Myburgh, J., \& Njorog, J. (2011). Emotional Intelligence: The Role of Accounting Education and Work Experience. Accounting education, 26(2), 267-286. http://dx.doi.org/10.2308/iace-10001 
De Villiers, R. (2010). The incorporation of soft skills into accounting curricula: Preparing graduates for their unpredictable futures. Meditari Accountancy Research, 18(2), 1-22. http://dx.doi.org/10.1108/10222529201000007

Dhess, J. (2011). Enhancing decisions and decision-making processes through the application of emotional intelligence skills.

Diamond, M. (2005). Accounting education, research and practice: After Enron, where do we go? European Accounting Review, 14(2), 353-362. http://dx.doi.org/10.1080/09638180500124855

Doran, M., Marvin, L., \& Smith, C. (1991). Determinants of student performance in accounting principles I and II. Issues in Accounting Education, 6(1), 74-84.

Ehsani, M., Saba, R. L., Jahanian, I., \& Kheirkhah, F. (2014). Communication between EI and academic condition in dental students of medical sciences university of Babol. Jondyshapour training development journal, 5(1), 80-87.

Fallan, L., \& Opstad, L. (2014). Beyond Gender Performance in Accounting: Does Personality Distinction Matter? Accounting Education: An International Journal, 23(4), 343-361. http://dx.doi.org/10.1080/09639284.2014.930693

Gardner, H. (1993). Frames of mind: The theory of multiple intelligences (10 anniversary ed.). New York, NY: Basic Books.

International Federation of Accountants. (2014). International Accounting Education Standard (IES). IES, 3, 44-49.

Kavanagh, M., \& Drennan, L. (2008). What skills and attributes does an accounting graduate need? Evidence from student perceptions and employer expectations. Accounting and Finance, 48(2), 279-300. http://dx.doi.org/10.1111/j.1467-629X.2007.00245.x

Khaef, F., \& Ahmadali, D. M. (2003). EI dimensions. Management and development journal, 18, 52-62.

McPhail, K. (2004). An emotional response to the state of accounting education: Developing accounting students' emotional intelligence. Critical Perspectives on Accounting, 15(4-5), 629-648. http://dx.doi.org/10.1016/S1045-2354(03)00050-9

Mostaghimi, M. J., \& Dehbashi, A. (2014). The relationship between manager's emotional Quotient and organizational commitment in TARAS. International Journal of Research in Organizational Behavior and Human Resource Management, 2(2), 304-311.

Nasir, M., \& Masrur, R. (2010). An Exploration of Emotional Intelligence of the Students of IIUI in relation to Gender, Age and Academic Achievement. Bulletin of Education and Research, 32(1), 37-51.

Paisey, C. (2009). Developing Skills via Work Placements in Accounting: Student and Employer Views. Accounting Forum, 64, 23-37.

Pan, P., \& Hector, P. (2011). Market relevance of university accounting programs: Evidence from Australia. Accounting Forum, 36, 91-108. http://dx.doi.org/10.1016/j.accfor.2011.11.001

Samouey, R. (2003). Translation and normalization of Bar-on EI Test. Sina Behavioral Sciences Research Institute.

Weber, M. R., Finley, D. A., Crawford, A., \& Rivera, D. J. (2009). An exploratory study identifying soft skill competencies in entry-level managers. Tourism and Hospitality Research, 9(4), 353-361. http://dx.doi.org/10.1057/thr.2009.22

Zavareghi, R., \& Fatahzade, K. (2006). Study of relationship between emotional intelligence and cognition in pre university woman and man students (Dissertation, School of Psychiatry and Social Sciences, Islamic Azad University) (In Persian).

\section{Copyrights}

Copyright for this article is retained by the author(s), with first publication rights granted to the journal.

This is an open-access article distributed under the terms and conditions of the Creative Commons Attribution license (http://creativecommons.org/licenses/by/3.0/). 